\title{
Secularism and Religious Nationalism: A Historical Study of Ethnic Conflict in Myanmar
}

\author{
Ram Hlei Thang ${ }^{1}$ \\ Chinbridge Institute, Myanmar
}

\begin{abstract}
Myanmar, also known as Burma, has been plagued by ethnic conflict and civil war for decades since its independence in 1948. Applying historical method, this study examines the relationship between the issue of secularism and ethnic conflict in the country by focusing on the rise of religious nationalisms. This study finds that the rise of Buddhist nationalism among Burmese majority, as well as the rise of Christian nationalism among minority ethnics-have challenged peaceful coexistence and vision of a secular state as aspirated by Burmese founding fathers. This study argues that this failure to adopt the principles of secularism was the root cause of ethnic conflict that has raged the country for over six decades.
\end{abstract}

Keywords: Secularism, Federalism, Ethnic Conflict, Religious Nationalism, Peaceful Coexistence

\section{Introduction}

Since 2011 Myanmar has seen a democratic transition from an authoritarian rule with the restoration of a quasi-civilian government led by President Thein Sein. However, ethnic conflict still continues and religious discrimination remains prevalent across the country. The peace process, popularly known as '21th Century Panglong Conference,' which was initiated in 2011, has also come to a halt on account of the non-secession issue and the relocation of ethnic armed groups in the conflict zone.

Myanmar has drawn international attention due to the violent conflict in Rakhine State that lead to rampant human rights violations and the fleeing of hundreds of thousands of Rohingyas to Bangladesh and neighboring countries (Velath \& Chopra, 2018, p. 75). The conflict has been further intensified and complicated by the imprisonment of a prominent Rakhine nationalist leader, U Aye Maung, and the clash between the Arakan Army (an Arakan ethnic armed organization who demand for autonomy) and the Tatmadaw (the government's armed forces). During this time, scholars, politicians and the international community were left to question why and how Myanmar, a

${ }^{1}$ Corresponding e-mail: ramhthang@gmail.com 
predominantly Buddhist country, fell back into violent conflict.

Recent studies on Myanmar (Anderson, 2014; Biver, 2014; Walton \& Heyward, 2014; Schissler et al., 2015 to name a few) focus on analyzing the problem based on the recent conflict and only cursorily question the root cause of such conflict. Furthermore, popular perception towards ethnic conflict resolution is dominated by the notion of democratization and federalism ( Sakhong, 2014; Dapice \& Vallely, 2013; Sen, 2002; Yawnghwe, 2002). As an insider researcher, the author strongly believes that religious matters are the prime key factor sparking ethnic conflict in Myanmar around the 1950s and 1960s and argues that ethnic conflict in Myanmar should be studied within the framework of secularism. The author would also like to shed light on the importance of secularism in state-building in a multi-cultural, multi-ethnic and multi-religious society like Myanmar.

The puzzle remains of why despite being envisioned as a secular state, Myanmar has instead been afflicted by religious tensions and ethnic conflict. This paper attempts to explore secularism in their approach to ethnic conflict resolution in Myanmar, which has been sidestepped by contemporary scholars. This paper identifies the root cause of ethnic conflict in Myanmar by exploring the relations between the issue of secularism and ethnic conflict in Myanmar. To answer this puzzle, this study employs a historical analysis method to analyze historical accounts of textual documents.

\section{Literature Review}

The word secularism has found different meanings in different periods of time and in different places. Whereas in countries such as the Netherlands, secularism means neutrality towards religious groups (Beaufort \& Schie, 2012), in countries like Turkey it takes the form of the secularization of public life (Daver, 1988). Yet, this study holds the French Laicite and American Church-State Separation as more defining examples of secularism. Barbier (2005) sought to provide the actual meaning of French Laicite by being critical to attempts to define secularism in terms of tolerance, pluralism and that of democracy. To him, such attempts often lead to misinterpretation and the transformation of its meaning or even to surreptitiously discarding it. Liogier (2009), Calhoun 
(2010), Nirenberg (2012) also postulate Laicite as having a negative connotation (exclusion of religion from state or religious instruction in public schools) introduced to confront the clerical influence in state affairs.

Secularism, on the other hand, finds different form in America. McClay (2007) argues that the U.S. Constitution and the First Amendment to the Constitution were not intended to create a purely secular government, neutral or indifferent to religion as opposed to irreligion. Greenawalt (2009) also agrees with McClay's argument. The U.S constitution does not only protect the Church from state manipulation and influence, but it also protects the state from the influence of the Church. At the same time, the Constitution guarantees freedom of religion and freedom of conscience. Secularism, thus is not a philosophy of life but rather is a political mechanism which tries to settle the encroachment of religion into the spheres of state and vice versa. Secularism as a philosophy emphasises the importance of science in the quest of truth, and places "service to humanity" as the highest virtue and the greatest duty of human beings (Holyoake, 2011).
The development of secularization project in Europe and America was also done by Shoji Ippei (2007). To him, secularism does not entail the secularization of human life, but rather a political principle that tackles the encroachments of religion in the state's spheres and vice versa. Secularism does not mean secularization of human life or belief, nor does it mean denying the importance of religious teachings for morality. The idea is that the Church should not exploit the state for its own good, likewise, the state should not exploit the church for its own political means. In Myanmar, secularism found a different meaning from the French Laicite and the American secularism outlined here.

Notwithstanding, secularism in Myanmar as envisioned by its founding fathers was not a stance against religion. It was neutrality of the state regarding religious matters. The Aung San' Draft of the 1947 Constitution provisioned that "the state shall keep neutrality in religious matter" (cited in Sakhong, 2005, p. 44). Regrettably, contemporary scholars rarely questioned secularism and the working of secularism in Myanmar. While Donald E. Smith (1965) described how religion encroached in to 
state affairs in the 1950s and 1960s, he asserted that Myanmar was a secular state in 1948 (Smith, 1965, p. 230). However, he did not define secularism nor did he look into how secular the country was.

Most scholars in their study of religion and politics in Myanmar emphasized the intertwinement of religion and nationalism, but rarely analyzed this matter from the framework of secularism. Scholars such as Aung-Thawin (2009) explain the intertwinement of Buddhism in Burmese nationalism and argue that there is a direct relationship between purity of the Sangha (the Buddhist monastic order) and the strength of the state. However, he is in support of the military coup and the state intervention in religious matter especially that of regulation of the Sangha.

Scholars also emphasized the role of religion in the social construction of Burmese identity and development of the society. Schober (2006), Walton (2012), Aljunied (2010), Keyes (2016), and James (2009) provide how Buddhism plays as the source of political philosophy and remains the socio-political vanguard of the people and serves as both unifying and rallying point for the masses. On the other hand, Sakhong (2005), Kham (2016), and Mang (2016) provide how Christianity constituted the foundation for national identity. The other group of studies on religion and politics in Myanmar focus on the role by which regions played in oppression and discrimination of other religious minority groups (Anderson, 2014; Biver, 2014; Schissler et al., 2015).

While the above-listed works give account of church-state relations and the role religion played in the sociopolitical life of the Burmese people, these works rarely question the issue of secularism and its relation to ethnic conflict. Therefore, this study will look at the church-state relations from the lens of secularism. The following section will focus on presenting literatures on the relations between religion and politics.

Secularism in the Formation of the Union of Myanmar

Some scholars on Burma have confused readers to consider Union of Burma as a nation taken back from the British. These scholars treat the history of the Union of Burma as if all the people of The Union of Burma were once under the successive Burman 
kingdoms invaded by the British and scattered through their divide-and-rule policy (see Aung-Thwin \& Aung-Thwin, 2012; Mynt-U, 2001; Smith, 1965). This is to be noted for students of politics in Burma: The Union of Myanmar is not a nation taken back from Britain but rather is a recent creation that emerged at Independence in 1948. At that time the Union of Myanmar was created by representatives of different nations who participated in the Panglong Conference. It was formed primarily to speed up independence from Great Britain (Panglong Agreement, 1947). When the Union was formed, it was envisaged by the founding fathers as a secular state in which all religions are equally respected.

Lamentably, one hardly sees scholars and politicians talking about secularism in the discourse of Panglong Conference or ethnic conflict. In fact, secularism was one of the most important principles in the formation of the Union. One may argue that secularism was not a party to the Panglong promises as it was not mentioned in the agreement. However, the founding fathers well understood the ethnic composition of the Union and sought to respond to this diversity by setting up a secular federal democracy.
When leaders of ethnic nationalities talk about autonomy, it includes the freedom to practice one's religion. For instance, when the Chin signatory, $\mathrm{Pu}$ Kio Mang of Hakha, said if they were to rule by themselves with their own Phunglam, they were willing to cooperate with the Burma Proper, he also meant the freedom to practice their religion (Sakhong, 2003, p. 212). The Chin word Phunglam incorporates culture, language, religion and political system. Yet, for ethnic nationalities who formed the Union of Myanmar, religion served as the most important component for preserving one's national identity. Some Burman ethnic leaders even went as far as to think that independence would be meaningless if Buddhism could not be made a state religion (Sakhong, 2005). Fortunately, the founding fathers recognized that secularism was the only way to respond to the diversity of the new Union and accommodate all ethnoreligious groups.

Aung San (the most prominent Burman leader during independent movement and Prime Minister of the Ministerial Burma), who persuaded minority ethnic leaders, repeatedly claimed that a clear line must be drawn between religion and politics. Under his 
leadership, a constitution for the union was drafted. According to Section 14 of the Draft constitution, the state should keep neutrality in religious matters, and, the abuse of religion for political purpose was also forbidden. At the same time, the freedom to practice and exercise one's religion is also guaranteed by the Draft constitution. Neutrality in religious matters, in this case, does not mean secularization of public life nor indifference to religious teachings and beliefs. It means equal treatment to all religions. While religious freedom was regarded as a part and parcel of the new agreement by some ethnic minority leaders, for Aung San, religion was a matter of individual conscience and usually it has nothing to do with mundane worldly affairs.

Thus, the founding father envisioned the Union to be a secular state at Panglong. In other words, secularism was a part and parcel of the Union formation set up by the founding fathers in response to the religious diversity of the Union.

\section{Challenges of Secularism in Myanmar}

The previous section argued that secularism was one of the most important principles for the formation of a modern state known as Union of Myanmar. However, Myanmar has seen religious tensions and ethnic conflict for several decades. Therefore, this section looks at what has happened to the envisioned secularism. Yet, despite being envisaged as a secular state Myanmar had become prone to religious tensions and ethnic conflict.

Secularism as a political principle may get challenged from different factors such as communism which oppose any religious belief, theocratism and even misinterpretation of the concept of secularism itself. For instance, Pollock (2009) argued that, "anyone arguing against secularism in this (well established) sense of a political principle is necessarily arguing at least for some belief group to have a privileged position in the state and probably therefore for restrictions on the freedom of religion or belief of others". This study argues that, in Myanmar, secularism, envisioned by the founding fathers is challenged from what this researcher called, the 'clash of religious nationalisms' or what may be called exclusive 'religious nationalism'. In fact, secularism is not against religious nationalism nor opposed to atheism. It is a political principle which tries to 
accommodate all religious and or nonreligious groups within a polity.

In the 1950s, Myanmar saw the rise of religious nationalism both among the Burman majority and minority ethnic nationalities. The problem with the rise of religious nationalism in Myanmar was that it was exclusive and not compromising. Since the assassination of Aung San, the architect of secularism in Myanmar, and his cabinet members in July in 1947, the Burman political leadership had been dominated by Buddhist nationalists. These leaders sought to revive the pre-colonial Burman nationalism which had been intensified in early $20^{\text {th }}$ century by colonial oppression. In fact, Buddhism severed as the most important component for Burman national identity since the foundation of the first Burman Kingdom of Pagan.

In precolonial Burma, religion and politics intertwined. The state and sangha mutually supported each other. Kings were regarded as protectors of the sangha and defenders of the faith. When the British destroyed that Kingdom, the people were deeply pained and disheartened by the fact that the supreme patron of the sangha was eliminated and Buddhism separated from the state. The Buddhist monks rendered a fierce resistance against the British annexation of the kingdom. According to Aung-Thwin, it was not only the first time the Buddhist monks took armed resistance against the state in the history of Myanmar, but was also because that was a foreign element that eliminated thathana-baing (the supreme patriarch of the sangha) (Aung-Thwin, 2009).

The centrality of Buddhism and nationalistic identity in Burma remains at the postcolonial era. With the creation of Young Men's Buddhist Association (YMBA), the traditional Burman nationalism had peaked in the early $20^{\text {th }}$ century. These young nationalists coined the slogan, "Buddha Batha, Myanmar Lumyo" which literally means, "to be a Myanmar is to be a Buddhist". To them Burma is for Burmans and Burmans are Buddhist. The pre-Panglong Burman nationalism can thus be called Buddhist Nationalism or Buddhist Burmanism.

In 1950s, some Burman nationalists sought to revive Buddhist Burmanism. The problem with such nationalism is that it sought to create a homogenous society. They wanted to create a Buddhist Burman state. The first thing 
they did was to reverse Aung San's secular principle and replace it with a more confessional religious principle, which provisioned Buddhism to a special position over other religions. The problem was that unlike precolonial Burma, Union of Myanmar is a multi-ethnic, multi-cultural and multireligious state. Buddhist Burmanism could not accommodate other religious groups particularly of minority ethnic nationalities. Therefore, when the Buddhist nationalists attempted to impose their Buddhist Burman state project, it received a severe resistance from minority ethnic nationalities particularly that of the Christian nationalists.

This resistance lead to the clash between religious nationalisms and envisioned secularism within the Union of Myanmar. To have a better understanding on how clash of religious nationalisms challenged secularism, it is important to look at the rise of Christian nationalism in Myanmar.

The Rise of Christian Nationalism and Its Challenges to Secularism in Myanmar

While Buddhism serves as the most important component for constructing
Burman nationalism, Christianity has asserted itself as an important element for the social construction of national identity amongst minority ethnic nationalities. The rapid conversion to Christianity, together with the introduction of written literature and schools enhanced national consciousness and identity construction among minority ethnic nationalities particularly for the Chin, Kachin and Karen (Smith, 1994). Christianity soon became a part and parcel of national identity construction. They started to identify their ethnicity with Christianity. As scholars asserted, Christianity became the "cornerstone of the modern Kachin identity" (Jaquet, 2015, p. 18), and "Christianity and Chin-ness became inseparably intertwined in a new Chin society" (Sakhong, 2005, p. 224). Thus, Christianity became the source of the social construction of national identity for these ethnic nationalities. Union of Myanmar, thus, saw the rise of Christian nationalism in the $20^{\text {th }}$ century.

Christianity does not only become a source of identity construction but also served as a unifying force for these minority ethnic nationalities by bringing people from different areas together under one roof such as Chin Hills Baptist 
Association (CHBA). This had led to a successful religious movement called Chin for Christ in One Century (CCOC) that virtually made the present Chin State a Christian State (Sakhong, 2005). The selfidentification with Christianity created a certain kind of religious nationalism that instilled a self-approved sense of being the "chosen people" among these ethnic nationalities.

The people who adopted Christianity see themselves as a people chosen by God to spread light throughout the world. They see even their own brethren who do not receive Christianity as people who are left in the dark. This juxtaposition is exemplified when $\mathrm{CCOC}$ designated the southern part of Chin State as 'Rammui,' which literally means Dark-land. Not only that, $\mathrm{CCOC}$ also created the idea of the 'God-given land'. They have a deep sense that their land is given by God for them and as the chosen people they have to protect their land as a God-given task.

The problem with Christian nationalism in Myanmar is that it is exclusive and reactionist. The minority ethnic nationalities saw Buddhism as a religion of the Burmans, a people who were hostile to them and the religion that is capable of hurting their very existence as a distinct nationality. For instance, one scholar pointed out that "Kachin never tended to convert to Buddhism for the simple reason that Buddhism was considered a religion of the Burman, who had been their enemy for centuries" (Dingrin in Mang, 2016, p. 161). The same can be said about the Chin, as Lehman has observed, Buddhism was seen as a religion of the Burman, a people who were hostile to them and conversion to Buddhism would amount to giving in-to the Burman (Mang, 2016; Sakhong, 2005). Christian nationalism in Myanmar thus was self-exclusive.

These Christian nationalists wanted to create autonomous Christian States for themselves in which they practice their Christian beliefs freely and impose Christian way of life to its people. Informed by the new conscious identity and bitterness against the Burmans, the Karen leaders developed the idea of independent nation-state and demanded independent state from the British in 1946 (KHCPS, 2006). Again, when the Union of Myanmar gained independence from Britain, dissatisfied with the demarcation of their territory and disarmament of the Karen veterans, the Karen nationalists declared armed revolution against the 
Union government in January 1949 and demanded an independent Karen State (Keenan, 2012). These moves were seen by Buddhists as a threat capable of hurting their goal of a unified nationality.

This rise of Christian nationalism among minority ethnic nationalities has repercussions for the materialization of the envisioned secularism. As seen above, it stirred the idea of Buddhism as a "foreign" religion capable of hurting their ethnic identity. While nationalism in itself do not pose challenge to secularism, like Buddhist Nationalism in Myanmar, the rise of Christian nationalism also challenges the idea of secularism envisioned for the Union. How these variations of religious nationalism challenged secularism will be discussed in the next section.

Clash of Religious Nationalisms and its Challenges to Secularism in Myanmar

Secularism as discussed above is a political principle that tries to accommodate all religious groups whether they are theistic religions or atheistic religions within a modern nation-state. however, secularism, which was envisioned as a response to the diversity of the Union found itself challenged by Buddhist and Christian religious nationalisms. While Buddhist nationalism sought to create a homogenous society based on Buddhist culture, Christian nationalism sought self-exclusion from other religious groups. This clash of religious nationalisms had a severe impact on secularism in Myanmar.

Buddhist nationalism which envisioned a Buddhist Burman state sought to impose Buddhist culture across the country. The attempt of creating a culturally homogenous society was facilitated by exploitation of state mechanisms, monks' involvement in state affairs, and elite competition for power or the exploitation of religion for political gains. This attempt has been seen by Christian nationalists as a threat to their existence as distinct ethnic nationalities. Therefore, they sought to resist the Buddhist efforts to create a Buddhist Burman state. The Buddhist nationalists saw the Christian nationalists' actions as anti-nationalist and anti-unionist. That intensified their religious nationalist sentiment and effort of creating a cultural homogenous society.

The first thing the Buddhist Nationalists did was allot a special 
position to Buddhism over other religions. That was followed by the creation of the Ministry of Religious Affairs and the Buddha Sasana Council in 1950 to promote and propagate Buddha Sasana (the Religion of Buddha or the Buddhist orientation of religious lives and yardstick for moral compass) and Buddhist culture. Accordingly, hundreds of missionary monks were sent and monasteries were built in the hills areas of the country formerly known as the Frontier Areas (the people who were not under the Burman Kingdom during the British invasion) (Mehden, 1961). Moreover, the special Ministry of Culture was created to promote the process of assimilation [of minority ethnic nationalities into Buddhist Burman society] (Cady, 1985, p. 638).

The uninvited involvement of sangha in state affairs was another facilitator in the attempt of creating homogenous society. Unlike precolonial Burma, sangha in independent Union of Myanmar was not legally entitled to involve in state affairs. Nevertheless, the sangha insertion in state affairs posed a challenge to secularism in the 1950s. What the Sangha had done was that first, the pongyis vigorously pressured the government to make the pongyi- kyaung (monasteries) into state primary schools where the presiding monk became the headmaster of that school.

Secondly, the monks bitterly opposed the government's policy to introduce instruction of Islam and Christianity in state schools in 1954. That was the most controversial issue in Myanmar politics during the mid1950s. The issue spread throughout the country and public feelings ran high, the rumor spread among the Buddhist laity that the government was determined to teach foreign religions (Islam and Christianity) to the Buddhist students. Prime Minister U Nu's suspension of Instruction of Buddhism in school in response to pongyis' repression to forbid instruction of Christianity and Islam further inflamed public feelings. Thousands of monks at Mandalay the former royal capital of Myanmar - protested against the Prime Minister and demanded that "Buddhism should not only be taught, but it should be the sole form of religious instruction. And if the Constitution stands in its way, it should be amended" (Smith, 1965). Thus, the pongyis' involvement in state affairs deepened the suspicion and fear of Buddhism as a religion capable of hurting the ethnic nationalities. 
The fear of being assimilated into Buddhist Burman society was further intensified by elite competition for power or exploitation of religion for political gain that facilitated the rise of religious nationalism and its challenge to secularism. This happened when the Anti-Fascist People's Freedom League (AFPFL) split into two factions, namely Nu-Tin faction and Ba-Nyein faction in the late 1950s. U Nu promised that they will make Buddhism a state religion if the $\mathrm{Nu}$-Tin faction wins the 1960 general election. The secular tradition had not totally disappeared during the 1950s. Leaders such as $U$ Ba Swe and U Kyaw Nyein still held the AFPFL's policy of secularism for the new Union. In the late 1950s religious nationalism was so prevalent that even these secularist leaders could not escape to resort to program which would promote Buddhism such as making Buddhism a compulsory subject and material support for monks and so on (Mehden, 1961). Moreover, U Ba Swe and U Kyaw Nyein had to struggle for months to prove that they were not atheists but devout Buddhists after accusing $U \mathrm{Nu}$ of exploiting religion for political gain. They invited the monks and served "suun", religious food offered to monks. Thus, in late 1950 s religion played the fulcrum of union politics. The most serious problem arose when U Nu's had to materialize his promise of making Buddhism a state religion.

Christian nationalists who had been seeing Buddhism as a foreign religion capable of hurting their very existence as distinct nationalities bitterly opposed the government's move of making Buddhism a state religion. Anti-State Religion Organizations were organized across the country and protested against State Religion Bill. The advisory commission was even met with violent protest (Smith, 1965, pp. 244-5). Despite all these protests and oppositions, the Bill was pushed through and passed in 1961. Thus, the founding fathers' vision of a secular state was buried in the clash of religious nationalisms.

The clash of religious nationalisms was ideologically informed by fear of others and exclusivist nationalisms. This contending fear and nationalism had dominated the union politics in the 1950s and 60s. The rise of Christian nationalism amongst minority ethnic nationalities has created fear in the majority Burman nationality because the later has seen the first as a threat capable of hurting the latter's goal 
of unified nationality. That in turn raised the volume of Burman Buddhist national sentiment among the majority group, which then led to the various moves of promoting Burman Buddhist culture such as creation of Buddha Sasana Council. The rise of Buddhist religious nationalism among the Burman majority with its manifestation in various programs through state mechanisms had in turn instilled fear in the ethnic minorities that lead to the various moves from demonstrations to armed resistance. This clash of religious nationalisms has effectively pushed the founding fathers' vision of a secular state aside.

Relations Between Secularism and Ethnic Conflict in Myanmar

The previous section shows that secularism has faced an adverse challenge in Myanmar because of the clash of Buddhist religious nationalism and the exclusivist Christian nationalism. This section examines the relations between the issue of secularism and ethnic conflict that has raged the country for several decades. It argues that the failure to adopt the principle of secularism, which led to clash of religious nationalism, was the root cause of ethnic conflict that has devastated the country for over six decades.

For some scholars and politicians, Myanmar's decades long conflict is the issue of authoritarian rule versus democracy (Sakhong, 2014). To others, the issues of federalism constituted the root cause of the conflict and the most important issue in rebuilding a peaceful union. For them federalism is the only tool to solve decades long ethnic civil war in Myanmar (Sen, 2002; Silverstein, 2002). The problem is that these scholars stress on only federalism and pays little attention to the issue of secularism, (mention why secularism must not be neglected). For instance, Sen (2002) has listed ten causes of ethnic civil war such as constitutional crisis, power politics and corruption, the invitation of military government in 1958 and the like. Unfortunately, secularism is not even included in these ten causes. Yet, the discussion in this study has found that the issue of secularism was the root cause for ethnic conflict in Myanmar.

Federalist scholars argued that the Union, envisioned at Panglong to be a federal state, but instead became not a federal but instead a unitary state when it gained independence from 
Britain. To them, this betrayal of the principle of federalism was the root cause that led to disunity, discontent and rebellion (Sakhong, 2005; Silverstein, 2002; Yawnghwe, 2002). However, a closer look at the history of ethnic conflict in Myanmar revealed a different story. There was no recorded serious dispute regarding the issue of federalism during the first years of Independence. More serious disputes were concentrated over religious issues such as religious teachings in government schools and universities (Smith, 1965; Crouch, 2015).

The open outburst of ethnic tensions occurred by the end of 1950s and escalated to its peak in 1960 when U Nu's government formed an advisory commission to advise on how to proceed to make Buddhism a religion of the Union (Smith, 1965). The commission drew protests from Christians, Muslims and other religious groups across the country and was even met with violent attacks during their tour to the former frontier areas. Even some Buddhists, especially minority ethnic leaders, such as Sao Shew Thaike, the first president of the Union, though devoted Buddhists themselves, severely opposed the state religion bill declaring that making Buddhism the state religion of the Union would be a violation of the Panglong Spirit (Smith, 1965). This state religion issue led to armed resistance from minority ethnic nationalities such as Kachin Independent Army (KIA) and Chin Liberation Army (Sakhong, 2014). Ethnic tensions on religious line was intensified by what is popularly known as the Fourth Amendment Bill which would protect the rights of religious minorities with emphasis on the rights to protection from insults and the rights to teach their religions. The Bill was pushed by $U \mathrm{Nu}$ to appease the anger of minority ethnic nationalities over State Religion. However, the Buddhist nationalists, both monks and laymen bitterly resented, protested and opposed the Bill because it was seen as a hinderance to their vision of homogenous society. The protests against the Fourth Amendment Bill even led to anti-Muslim riots in the Suburbs of Yangon (James, 2009). Thus, in 1950s and 1960 s, the country had seen chaos, controversies and riots due to clash of religious nationalisms.

The question is, why did Myanmar see clash of religious nationalism in the 1950s and 1960s? The root of religious tensions can be traced back to constitutional arrangement 
during the independence period. Aung San's secular principle was replaced with a more confessional religious constitution that provisioned one religion to hold a special position over the others. This deviation from the secularism principle has begotten the seeds of ethnic tensions, distrust and conflicts. It paved the way for Buddhist nationalists to exploit state mechanisms in materializing their vision of homogenous society. The deviation first led to the creation of Ministry of Religious Affairs, and then followed by the creation of Buddha Sasana Council, and finally State Religion in 1961 . This also led to what some scholars called "Federal Movement" (a call for conference that led $\mathrm{U} \mathrm{Nu}$ to held seminar to discuss matters of constitutional arrangement).

As minority ethnic nationalities could not resist the state religion bill in parliament, the fear and feeling of vulnerability of assimilation into Buddhist Burman cultural society increased. In response to the State Religion law, minority ethnic leaders called a conference and proposed to amend the union constitution in accordance with Aung San's version that postulated secular state. The conference unanimously agreed and demanded to amend the Union Constitution in accordance with the original Draft that provisioned a Secular Federal Union. In response to the demand, $\mathrm{U}$ Nu called a national seminar to discuss matters of constitutional amendment.

Thus, in 1950s and 1960s, the union politics was dominated by religious issues. In these years, ethnic tensions, riots and armed revolutions took place across the country. Civil unrests and religious tensions together with the federal seminar caused by clash of religious nationalisms was interpreted by General Ne Win as a secession movement. He spread a propaganda that federalism would lead to the secession of minority ethnic nationalities from the Union and that the military need in the name of saving the Union from disintegration. Therefore, to save the Union from disintegration the military came to power in March 1962. In this way, ethnic armed rebellions, civil unrests and the federal movement triggered by religious controversies paved the way for Ne Win to coup the political power in 1962. As a result, all major minority ethnic groups resorted to armed resistance against the Union government.

The Union then fell into the pit of authoritarian rule and ethnic civil war for 
several decades. Therefore, it can be said that the betrayal of the secular principle that finally led to creation of State Religion in 1961 was the trigger that exploded ethnic conflict in Myanmar.

\section{Conclusion}

This research has found that though it was envisioned by the founding fathers to be a secular state, the Union of Myanmar has seen religious tensions and ethnic conflict because of the clash of religious nationalisms. A clash between Buddhist nationalism accompanied by exploitation of state mechanism, uninvited pongyi's involvement in state affairs, and elite competition for power or exploitation of religion for political gain and Christian nationalism accompanied by exclusivist reactions that instilled fear in the Buddhist nationalists put the union into a pit of ethnic conflict for several decades.

This research also found that the root cause of ethnic conflict in Myanmar was failure to adopt the principles of secularism that begotten the seed of ethnic tension, disunity, discontent and conflict.

In order to restructure a peaceful union, it is important to consider the issue of secularism not only because of the failure to adopt secular principle being the root cause of ethnic conflict, but also because without secularism it is hard to have peaceful coexistence in a Union with multi-religious, multicultural and multi-ethnic nationalities like Union of Myanmar. Hence, the task for the citizens of the Union of Myanmar and future researchers is to find ways to reconcile different nationalisms, promote the idea of secularism in which all religions are equally respected and create platforms for peaceful coexistence of different religious and ethnic identities without hurting their religiosity and nationality.

\section{References}

Aljunied, M. A. (2010). Politics and Religion in Contemporary Burma: Buddhist Mon

ks as Opposition. Jonsei Journal of International Studies, 2(1), 37-49.

Anderson, K. (2014). Truth and Tribe: Religious and Ethnic Nationalism in Burma. The Sentineil Project.

Aung-Thwin, M. A. (2009). Of Monarchs, Monks, and Men: Religion and State in Myanmar (No. 127).

Aung-Thwin, M. A., \& Aung-Thwin, M. (2012). A History of Myanmar since Ancient Times: Traditions and 
Transformation. London: Reaktions Books.

Barbier, M. (2005). Towards a Definition of French Secularism. LeDebat, 134, 1-24.

Beaufort, F. de, \& Schie, P. van. (2012). The Separation of Church and State in the Netherlands. In Separation of Church and State in Europe: With views on Sweden, Norway, United Kingdom \& Ireland, The Netherlands, France, Portugal, Italy and Slovenia (In Beaufor). Brussel: European Liberal Forum.

Biver, E. (2014). Religious Nationalism: Myanmar and the Role of Buddhism in Anti-Muslim Narratives; An analysis of Myanmar's Ethnic Conflicts through the Lens of Buddhist Nationalism. Lund University.

Cady, F. J. (1985). A History of Modern Burma. New York: Cornell University Press.

Calhoun, C. (2010). Rethinking Secularism. The Hedgehog Review, 12(3), 35-48.

Crouch, Melissa. (2015). Constructing Religion by Law in Myanmar. The Review of Faith \& International Affairs,13(4), 1-11.

Dapice, D., \& Vallely, T. (2013). Against the Odds: Building a Coalition Using a
New Federalism for Unity and Progress in Myanmar. Massachusetts.

Daver, B. (1988). Secularism in Turkey. Ankara University SBF Journal, 43(1), 29-40.

Greenawalt, K. (2009). Secularism, Religion, and Liberal Democracy in the United States. Cardozo Law Review, 30(6), 2383-2400.

Holyoake, G. J. (2011). The Principles of Secularism. London: Austin. \& Co. Ippei, S. (2007). Secularism in America: A Brief History of Non-Religion Movement. Nanzan Review of American Studies, 29, 97-106.

James, H. (2009). Secularism and Violence in the Buddhist State: The Case of Thailand and Myanmar.

Jaquet, C. (2015). The Kachin Conflict: Testing the Limits of the Political Transition in Myanmar. Bangkok: IRASEC.

Keenan, P. (2012). The Karen National Union Negotiations 1949-2012. Chiang Mai: The Burma Centre for Ethnic Studies.

Keyes, C. (2016). Theravada Buddhism and Buddhist Nationalism: Sri Lanka, Myanmar, Cambodia, and Thailand. The Review of Faith \& International Affairs, 14(4), 42-52. 
Kham, Z. K. (2016). Burmese Nationalism and Christianity in Myanmar: Christian Identity and Witness in Myanmar Today.

KHCPS. (2006). The Karens and Their Struggle for Freedom. Mae Sot.

Liogier, R. (2009). Laicite on the Edge in France: Between the Theory of Church-State Separation and the Praxis of State-Church Confusion. Macquarie Law, 9, 25-45.

Mang, P. Z. (2016). Buddhist Nationalism and Burmese Christianity. Studies in World Christianity. https://doi. org/10.3366/swc.2016.0147

McClay, W. (2007). Religion \& Secularism: The American Experience. The Faith Angle Forum, 1-26.

Mehden, F. Von Der. (1961). Buddhism and Politics in Burma. The Antioch Review, 12(2), 166-175.

Mynt-U, T. (2001). The Making of Modern Burma. New York: Cambridge University Press.

Nirenberg, S. (2012). The Resurgence of Secularism: Hostility Towards Religion in The United States and France. Washington University Jurisprudence Review, 5(1), 131161.

Panglong Agreement. (1947). Retrieved from https://peacemaker.un.org/ sites/peacemaker.un.org/files/ MM_470212_Panglong\%20 Agreement.pdf

Pollock, D. (2009). The Challenge of Secularism.

Sakhong, L. H. (2014). The Dynamics of Sixty Years of Ethnic Armed Conflicts in Burma (Sakhong \& Keenan, Ed.). Chiang Mai: BCES Press.

Sakhong, Lian H. (2005). Federalism, Constitution Making and State Building in Burma: Finding Equilibrium between Nation-building for Self-rule and State-building for Share-rule in Federalism (W. and Sakhong, Ed.). Chiang Mai: UNLD Press.

Sakhong, Lian H. (2003). In Search of Chin Identity: A Study in Religion, Politics and Ethnic Identity in Burma. Copenhagen: NIAS Press.

Schissler, M., \& Walton, M.J., \& Thi, P. P. (2015). The Roots of Religious Conflict in Myanmar: Understanding Narratives is an Important Step to Ending Violence.

Schober, J. (2006). Buddhism in Burma: Engagement with Modernity (Buddhism i; S. C. Brekwitz, Ed.). California: ABC-CLIO.

Sen, K. . (2002). Federalism with A New Twist: Burma's Only Option. Legal Issues on Burma Journal, 11, 31-40. 
Silverstein, J. (2002). Federalism as a Solution to the Ethnic Problem in Burma. Legal Issues on Burma Journal, 11, 3-12.

Smith, D. E. (1965). Religion and Politics in Burma. New Jersey: Princeton University Press.

Velath, Priyanca M. and Kriti Chopra. (2018). The Stateless People: Rohingya in Hyderabad. In Chaudhury, S.B.R and Ranabir Samaddar (ed) The Rohingya in South Asia: People Without State. London: Routledge.
Walton, J. M. (2012). Politics in the Moral Universe: Burmese Buddhist Political Thought. University of Washington, Washington.

Walton, J. M. and Susan Hayward. (2014). Contesting Buddhist Narratives: Democratization, Nationalism, and Communal Violence in Myanmar. Policy Studies. Honolulu: East-West Center.

Yawnghwe, C.-T. (2002). Federalism: Putting Burma Back Together Again. Legal Issues on Burma Journal, 11, 55-68. 